\title{
Hasat Öncesi Sulamayı Sonlandırma Zamanının Damla Yöntemiyle Sulanan Salçalık Domatesin Verim ve Kalitesi Üzerine Etkisi
}

\author{
'Mehmetcan AȘIK \\ 2*Hayrettin KUȘÇU \\ 'Uludağ Üniversitesi Fen Bilimleri Enstitüsü Biyosistem Mühendisliği Anabilim Dalı \\ Uludağ Üniversitesi Ziraat Fakültesi Biyosistem Mühendisliği Bölümü
}

\begin{abstract}
*Sorumlu yazar e-mail (Corresponding author e-mail): kuscu@uludag.edu.tr
Geliș tarihi (Received) : 01.10.2020

Kabul tarihi (Accepted): 06.01.2021

DOI: $10.21657 /$ topraksu. 803296
\end{abstract}

\section{Öz}

Bursa koșullarında 2019 yılında yapılan bu araștırmada, salçalık Heinz-1 015 çeșidi domateste, hasattan 4 (S1), 8 (S2), 12 (S3) ve 16 (S4) gün önce sulama suyunun kesilmesinin domates verimi ve kalitesi üzerine etkileri araștııımıștır. Deneme, tesadüf blokları deneme desenine göre 3 tekrarlamalı olarak yürütülmüștür. Deneme sonucunda, konulara uygulanan mevsimlik sulama suyu miktarı 317- 377 mm arasında değișim göstermiș, en yüksek bitki su tüketimi 512 mm ile S1 konusundan en düșük ise 475 mm ile S4 konusundan belirlenmiștir. En yüksek verim değerleri S1 ve S2 konusunda gerçekleșmiș ve son sulamanın hasattan önce kesilme süresi arttıkça verim değerleri azalmıștır. Domatesin su üretkenliği ve sulama suyu üretkenliği değerleri sırasıyla 13,1-21,6 kg m ile 19.6-30.3 $\mathrm{kg} \mathrm{m}^{-3}$ arasında değișmiș, en yüksek değerler $\$ 2$ en düșük ise $\$ 4$ deneme konusunda belirlenmiștir. Domates meyvelerindeki en yüksek briks değeri 6,53 ile \$4 deneme konusunda ölçülmüș ve hasada yakın sulama yapıldıkça briks değerlerinin düștüğü saptanmıștır. En büyük meyve sertliği değerleri 1,13 kg ve 0,99 kg olarak sırasıyla S4 ve S3 konularından elde edilmiștir. Meyve rengi parametrelerine ilișkin L, a, b, C ve h değerlerinin sırasıyla 36.93-37.60, 36.37-38.40, 25.73-26.90, 44.33-46.30, 33.93-36.00 arasında değiștiği saptanmıștır. Salçalık domatesin sulama suyu miktarına ve hasattan önce kesilme zamanına duyarlı olduğu, son sulama uygulamasının hasattan 8 gün önce kesilmesi durumunda verimde büyük bir azalma olmaksızın kalite parametrelerinde iyileșmeye yol açtığı sonucuna varılmıștır.

Anahtar Kelimeler: Bitki su tüketimi, briks, renk, sertlik, su üretkenliği

\section{The Effect of Cutting Time of Irrigation before Harvest on Yield and Quality of Processing Tomatoes Irrigated by Drip Method}

\begin{abstract}
In this study conducted in 2019 in Bursa conditions, the effects of cutting irrigation water 4 (S1), 8 (S2), 12 (S3) and 16 (S4) days before harvest on tomato yield and quality were investigated in this study conducted on tomato paste Heinz-1015 variety. The experiment was carried out in 3 replications according to the randomized complete block design. The amount of seasonal irrigation water applied to the experimental treatments varied between 317 - $377 \mathrm{~mm}$, the highest evapotranspiration (ET) was determined from S1 with $512 \mathrm{~mm}$ and the lowest ET was determined from S4 with $474 \mathrm{~mm}$. The highest yield values were realized in S1 and S2 and the yield values decreased as the last irrigation
\end{abstract}


was cut before harvest increased. The water productivity and irrigation water productivity values of tomatoes varied between 13.1-21.6 kg m$~^{-3}$ and 19.6-30.3 $\mathrm{kg} \mathrm{m}^{-3}$, respectively, the highest values were determined in $\mathrm{S} 2$ and the lowest in $\mathrm{S} 4$ treatment. The highest Brix value in tomato fruits was measured at S4 with 6.53 and it was determined that Brix values decreased as irrigation was done close to harvest. The highest fruit hardness values were $1.13 \mathrm{~kg}$ and $0.99 \mathrm{~kg}$ from S4 and S3 treatments, respectively. L, a, b, $C$ and $\mathrm{h}$ values for fruit color parameters were found to vary between 36.93-37.60, 36.37-38.40, $25.73-26.90,44.33-46.30,33.93-36.00$, respectively. It is concluded that processing tomato is sensitive to the amount of irrigation water and time of cessation of irrigation before harvest, and if the last irrigation application is cut eight days before harvest, it leads to an improvement in quality parameters without a significant decrease in yield.

Keywords: Crop evapotranspiration, water productivity, processing tomatoes, Brix, color, hardness

\section{Giriș}

Türkiye'de üretilmekte olan sebze miktarı her geçen yıl artmaktadır. Nitekim 2017 Türkiye İstatistik Kurumu (TÜIK) verilerine göre sebze üretimi 30 milyon tondan fazladır. Sebze üretiminde en fazla orana sahip olan kısmı, meyvesi yenilebilen sebzeler (domates, biber, patlıcan, karpuz, vb.) olușturmaktadır. Bu üretimler dikkate alındığında toplam sebze üretiminin \%40-45'lik bölümünü domates (Solanum lycopersicum) olușturmaktadır (Güvenç, 2019). Ülkemizde üretilen domatesin çoğu salçalık domates olarak üretilmektedir. Salçalık domates üretiminde, Marmara ve Ege Bölgeleri bașta gelmektedir. İklimsel veriler göz önüne alındığında, bu bölgelerimizin domates yetiștiriciliğine daha uygun olduğu görülmektedir. Ülkemizde salçalık domates üretiminde ilk sırada yer alan iller sırası ile Bursa (994057 ton), İzmir (738252 ton) ve Manisa'dır (702491 ton) (TÜiK, 2018). Dünyada domates üretiminde öncü ülkelerin bașında Çin, Hindistan ve Nijerya gelmektedir. Türkiye ise dünyada domates üretiminde 4. sırada gelmektedir.

Domatesin insan beslenmesinde vazgeçilmez bir rolünün olmasının yanı sıra zengin aroma bileșikleri ve biyoaktif bileșik kaynaklarının da olması sebebiyle gıda endüstrisinde çok çeșitli kullanım alanlarına sahiptir. (Aguayo vd., 2009; Kelebek vd., 2017). Domates, gıda sanayisinde domates suyu, ketçap, salça, sos, çorba ve reçel üretiminde kullanılmaktadır (Jumah vd., 2007).

Domateste, uygulanan su miktarı meyve verimini arttıırken, buna karșın meyvelerin suda çözünür katı madde içeriği (briks derecesi), likopen ve toplam polifenol içeriğini önemli ölçüde düșürmektedir. Askorbik asit söz konusu olduğunda ise optimum su temin koșullarında daha yüksek asitlik elde edilmektedir (Helyes vd., 2012).
Kușçu vd. (2014a) tarafindan Bursa koșullarında gerçekleștirilen çalıșmada domateste briksin toprak su içeriğinden önemli ölçüde etkilendiği belirtilmiș ve mevsimlik sulama suyu miktarındaki artıșla briksin önemli ölçüde azaldığı ve en düșük sulama suyu seviyesi için 6 briks ve en yüksek sulama seviyesi için 5 briks olarak raporlanmıștır. Güney İtalya Sicilya koșullarında gerçekleștirilen bir çalıșmada Brigade çeșidi kullanıımıș olup en yüksek briks değerleri (7.60-6.35) denemenin kurulmasından sonra sulamanın yapılmadığı koșulda, en düșük briks değerleri (4.80-4.90) ise her iki yılda da tam sulamanın yapıılığı koșulda ölçülmüștür (Patanè vd. 2011). Cetin ve Uygan (2008), domates bitkisinde damla sulama koșullarında lateral arlıkları, sulama rejimleri ve ekim geometrilerinin verim, sulama suyu üretkenliği ve net gelir üzerindeki etkisini belirlemek amacıyla Eskișehir koșullarında Dual Large domates çeșidi ile yaptıkları çalıșmada ortalama olarak verim değerlerinin 88.9

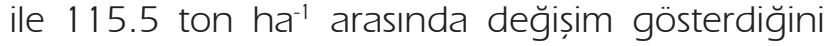
raporlamıșlardır. Marouelli vd. (2004) tarafından Brazilya koșullarında gerçekleștirilen çalıșmada, en yüksek pazarlanabilir meyve verimi (8.23 ton ha $^{-1}$ ), son sulama uygulamasının denemenin bașlangıcından 68 gün sonra (hasattan 21 gün önce) gerçekleștirildiği koșulda saptanmıștır. Çetin vd. (2008), damla sulama yöntemiyle sulanan domateste, intiyaç duyulan su miktarını belirlemek için bitki örtü yüzdesini kullanarak su tasarrufu yapmanın ve verimi artırmanın mümkün olup olmadığını araștırmıșlardır. Buna göre, en yüksek meyve verimini (134.8 ton ha-1 ${ }^{-1}$, A sınıfı buharlașma kabından buharlașan suyu referans alarak bitki gelișme dönemlerine göre farklı bitki katsayılarının (fide dikim zamanından çiçeklenme așamasına kadar 0.50; çiçeklenme așamasından ilk hasada kadar 1.0 ve ilk hasattan son hasada kadar 0.75 ) 
kullanıldığı ve ıslatılan alan yüzdesinin bitki örtü yüzdesine bağlı olarak değiștiği koșullarda elde etmișlerdir.

Salça için yetiștirilen domateste, meyvedeki suda çözünür katı madde içeriği (briks) önemli bir kalite faktörü olup salça verimini etkileyen ana parametredir (Johnstone vd., 2005). Briks değerinin yüksek olması, salça üretiminde buharlaștırma amacı ile kullanılan ekipmanların daha az kullanılmasını sağlamaktadır. Bu ise fabrika için önemli ölçüde hem doğal gaz hem de elektrik maliyetinin düșürülmesinde önemli rol oynamaktadır. Bu yüzden salçalık domates ișleyen fabrikalar için briks değeri önemli bir kriterdir. Ancak çiftçiler arazilerinden daha fazla verim almak istediği için briks değerlerine fazla önem vermemekte ve hasat zamanına kadar sulamaya devam etmektedir. Bu durum ise, domatesin sahip olduğu briks değerini oldukça düșürmektedir. Her ne kadar çiftçi için olumlu bir durum olsa da fabrikalar için de aynı derece olumsuz sonuçlar doğurmakta ve daha maliyetli bir üretime neden olmaktadır. Bu nedenle 2019 yılında Bursa koșullarında yapılan bu çalıșmanın amacı, salçalık domates üretiminde hem çiftçi hem de sanayi üretimi açısından genel bir değerlendirme yapmak için, damla sulama koșulları altında hasattan belirli süre önce sulamanın kesilip bu durumun domates verimi ve briks değeri bașta olmak üzere domatesin diğer kalite kriterleri hakkında verileri ortaya koymak amaçlanmıștır.

\section{MATERYAL VE YÖNTEM}

Bu çalıșma, 2019 yılı tarla domatesi yetiștirme döneminde (mayıs ve ağustos), Bursa Uludağ Üniversitesi Ziraat Fakültesi Tarımsal Uygulama ve Araștırma Merkezi deneme arazisinde yürütülmüștür. Araștırmanın gerçekleștirildiği alanın deniz seviyesinden ortalama olarak yüksekliği $100 \mathrm{~m}$ olup $40^{\circ} 11^{\prime}$ kuzey enlemi, $29^{\circ}$ 04' doğu boylamında yer almaktadır. Yetiștiricilik mevsimi boyunca ortalama bağı nem değeri \%66 seviyesinde gerçekleșmiștir. Diğer taraftan aylık ortalama sıcaklık değerleri, mayıs ayında $19,7^{\circ} \mathrm{C}$ iken daha sonraki aylarda artıș göstermiș ve en yüksek sıcak değeri ise ağustos ayında $25,1^{\circ} \mathrm{C}$ olarak görülmüștür. Araștırma alanına ait toprakların fiziksel ve kimyasal özellikleri Çizelge 1'de verilmiștir. Bitkisel materyal olarak erkenci orta grupta yer alan Heinz-1015 çeșidi sanayi domatesi kullanıımıștır.

Tarla denemeleri tesadüf blokları deneme desenine göre 3 tekrarlı olacak șekilde yürütülmüștür. Deneme konuları bloklar içinde rastgele olarak dağıtımıștır. Deneme parselleri, sıra aralığı $140 \mathrm{~cm}$ ve sıra üzeri $30 \mathrm{~cm}$ olacak biçimde $4.2 \mathrm{~m} \times 5 \mathrm{~m}=21 \mathrm{~m}^{2}$ lik bir alanda yürütülmüștür. Parseller ve bloklar arasında 2 m mesafe bırakılmıștır. Deneme konuları hasattan 4 gün (S1), 8 gün (S2), 12 gün (S3) ve 16 gün (S4) önce sulama suyunun kesilmesi biçiminde olușturulmuștur.

Fide dikiminden 1 gün önce, 0-90 cm toprak derinliğinde gravimetrik yöntem ile toprak örneği alınarak tarla kapasitesi ile mevcut nem arasındaki fark belirlenmiș ve mevcut nemin tarla kapasitesine ulaștırılması gereken sulama suyunun yarısı deneme parsellerine verilmiștir. Devamında, 3 Mayıs 2019 tarihinde, 3-4 yapraklı domates fideleri deneme parsellerine elle dikilmiștir. Dikim ișleminin ardından mevcut nemin tarla kapasitesine ulaștırıması gereken su miktarının ikinci yarısı bitki kök bölgesine damla sulama sistemi aracılığı ile

Çizelge 1. Araștırma alanı topraklarının bazı fiziksel ve kimyasal özellikleri

Table 1. Some physical and chemical properties of the research area soils

\begin{tabular}{|c|c|c|c|c|c|c|c|}
\hline $\begin{array}{l}\text { Toprak Derinliği } \\
(\mathrm{cm})\end{array}$ & $\begin{array}{l}\text { Kil } \\
(\%)\end{array}$ & $\begin{array}{l}\text { Kum } \\
(\%)\end{array}$ & $\begin{array}{l}\text { Silt } \\
(\%)\end{array}$ & Bünye Sınıfı & $\begin{array}{l}\text { Tarla Kapasitesi } \\
\text { (Kuru Ağırlık \%) }\end{array}$ & $\begin{array}{l}\text { Solma Noktası } \\
(\text { Kuru Ağırlık \%) }\end{array}$ & $\begin{array}{l}\text { Hacim Ağırlığı } \\
\left(\mathrm{g} \mathrm{cm}^{-3}\right)\end{array}$ \\
\hline $0-30$ & 49.5 & 24.3 & 26.2 & Kil & 38.2 & 27.1 & 1.35 \\
\hline $30-60$ & 50.5 & 23.3 & 26.2 & Kil & 40.0 & 27.0 & 1.36 \\
\hline $60-90$ & 53.5 & 21.9 & 24.6 & Kil & 43.0 & 26.8 & 1.34 \\
\hline $90-120$ & 40.5 & 21.6 & 37.9 & Kil & 40.1 & 23.2 & 1.38 \\
\hline $\begin{array}{l}\text { Toprak Derinliği } \\
(\mathrm{cm})\end{array}$ & $\begin{array}{c}E C \\
\left(\mathrm{dS} \mathrm{m}^{-1}\right)\end{array}$ & $\mathrm{pH}$ & Kireç (\%) & $\begin{array}{c}\text { Saturasyon } \\
(\%)\end{array}$ & $\begin{array}{c}\text { Organik Madde } \\
(\%)\end{array}$ & $\begin{array}{c}\mathrm{P}_{2} \mathrm{O}_{5} \\
\left(\mathrm{~kg} \mathrm{da}^{-1}\right)\end{array}$ & $\begin{array}{c}\mathrm{K}_{2} \mathrm{O} \\
\left(\mathrm{kg} \mathrm{da}^{-1}\right)\end{array}$ \\
\hline $0-30$ & 0.45 & 6.1 & 0.0 & 101 & 0.72 & 8.9 & 46 \\
\hline $30-60$ & 0.45 & 6.4 & 0.0 & 109 & 0.43 & 3.5 & 36 \\
\hline $60-90$ & 0.79 & 7.1 & 1.3 & 110 & 0.57 & 8.1 & 39 \\
\hline $90-120$ & 0.64 & 8.0 & 43.7 & 101 & 0.17 & 6.9 & 25 \\
\hline
\end{tabular}


verilmiș ve deneme bașlatılmıștır. Tüm parsellere eșit olacak biçimde hektara $180 \mathrm{~kg} \mathrm{~N}$ ve $120 \mathrm{~kg}$ $\mathrm{P}_{2} \mathrm{O}_{5}$ verilmiștir. Fosforlu gübrenin (Triple Süper Fosfat, \%43-44 $\mathrm{P}_{2} \mathrm{O}_{5}$ ) tamamı azotlu gübrenin ise yarısı fide dikiminden önce toprağa taban gübresi olarak Amonyum Nitrat (\%33 N) formunda uygulanmıș, azotlu gübrenin diğer yarısı ise 11 Haziran 2019 tarihinde Amonyum Sülfat 1\%21 $\mathrm{N}$ ve \%24 S) formunda doğrudan toprağa uygulanmıștır (Kuscu vd., 2014a). Toprak analiz sonuçlarının potasyum içeriğinin yeterli olduğunu göstermesi nedeniyle potasyumlu gübreleme yapılmamıștır. Mayıs ayının 13 ve 14. günlerinde çapa yapılarak boğaz doldurma ve yabancı otlarla mücadele ișlemleri gerçekleștirilmiștir. Yabancı otlarla mücadele, deneme boyunca sürekli olarak gerçekleștirilmiștir. Yaprak biti ile mücadele için 4A grubu $350 \mathrm{~g} / \mathrm{I}$ Imidacloprid etken madde içeren süspansiyon konsantre Confidor SC 350 ticari isimli insektisit, etiketinde belirtilen kullanım dozu doğrultusunda uygulanmıștır. Bunun yanında külleme mücadelesi için $200 \mathrm{~g} / \mathrm{l}$ Tebuconazole ve $120 \mathrm{~g} / \mathrm{I}$ Azoxystrobin içeren süspansiyon konsantre Azimut 320 SC fungusit uygulanmıștır.

Sulama denemeleri süresince uygulanan sulama suyu miktarının tespiti için $(\mathrm{mm}) ; \mathrm{I}=\mathrm{A} x$ Ep $\times$ Ea $\times$ kpc $\times$ P eșitliği kullanılmıștır. Eșitlikte, I: Sulama suyu (L), A parsel alanı $\left(21 \mathrm{~m}^{2}\right)$, Ep A sınıfı buharlașma kabından buharlașan su miktarını (mm) göstermektedir. Damla sulama sistemi için su uygulama etkinliği Ea=0.90 olarak alınmıștır. Bu çalıșmada sulamalara son verilme zamanının bitki üzerindeki etkileri araștırıldığından herhangi bir su stresi olușturmamak için bitki katsayısı deneme süresince $k p c=1$ olarak alınmıștır. Islatılan alan yüzdesi (P), bitki örtü yüzdesine eșit olacak biçimde deneme süresince her sulama öncesinde ölçülerek belirlenmiș ve hiçbir zaman \%30'un altında alınmamıștır (Çetin vd., 2008; Yıldırım, 2008; Tarı ve Sapmaz, 2017). Sulama, yörede domatesin damla sulama uygulamalarında yaygın olarak tercih edildiği 4 günlük aralıklarla gerçekleștirilmiștir.

Bitki su tüketimi, $E T=1+P \pm D S-D-R$ formülünden yararlanılarak hesaplanmıștır (Garrity vd., 1982). Eșitlikte; ET = Bitki su tüketimi, mm, I = Uygulanan sulama suyu miktarı $(\mathrm{mm}), \mathrm{P}=$ Etkili yağıș $(\mathrm{mm})$, (Parsellerin etrafı çevrili olduğu için tüm yağıșlar etkili yağıș olarak kabul edilmiștir), DS = İki toprak suyu ölçümü arasındaki değișim $(\mathrm{mm} / 90 \mathrm{~cm}), \mathrm{D}=$ Derine sızma $(\mathrm{mm}), \mathrm{R}=$ Yüzey akıș miktarını (mm) göstermektedir, Yağıș miktarı,
Bursa Uludağ Üniversitesi yerleșkesinde yer alan meteoroloji istasyonundan alınmıștır. Bunun yanı sıra uygulanan su miktarı, her bir sulama düzeyi için su sayacı yardımıyla ölçülmüștür. İki toprak suyu ölçümü arasındaki değișim gravimetrik yöntem ile hesaplanmıștır. Bitki su tüketiminin belirlenmesinde toprağın 0-60 cm'lik bölümünde bulunan su içeriği dikkate alınmıștır. Diğer 60$90 \mathrm{~cm}$ 'lik kısımda ise meydana gelen olası bir nem artıșı derine sızma olarak değerlendirilmiștir. Kullanılan sulama suyu, damla sulama yöntemiyle kontrollü bir șekilde gerçekleștirildiğinden, yüzey akıș, toprak su bütçesi eșitliğinde dikkate alınmamıștır. Sulama suyu üretkenliği (IWPP) ve su üretkenliği (WP) değerlerinin hesaplamasında așağıdaki eșitlikler kullanılmıștır (Bos, 1980; Tarı ve Sapmaz, 2017).

$$
\begin{aligned}
& \text { WP }=\text { YLD } / \text { ETa } \\
& \text { IWP }=\text { YLD } / \text { IRGA }
\end{aligned}
$$

Eșitlikte; YLD = Konulara göre meyve verimi (t ha1), $\mathrm{ETa}=$ Konulara göre mevsimlik gerçek bitki su tüketimi (mm) ve IRGA = Konulara göre mevsimlik sulama suyu miktarı ( $\mathrm{mm}$ ) olarak tanımlanmaktadır.

Meyve verimi; her parselden hasat edilip tartılan kırmızı domates meyvelerinin ağırlığının, hektar verimine dönüștürülmesiyle belirlenmiștir. Tek meyve ağırlığı; hasatta her deneme parselinden rastgele toplanan 10 adet meyvenin ağırlıkları tek tek tartılarak kayıt altına alınmıs ve ortalaması alınarak tek meyve ağırlığı belirlenmiștir. Daha sonra her parsel için rastgele seçilen 3 adet sağıklı meyve üzerinde kalite özellikleri belirlenmiștir. Domates meyvelerindeki briks derecesini belirlemek için dijital bir refraktometre $(\mathrm{H}) 96800$, Hanna Instruments) kullanılmıștır. Dijital bir $\mathrm{pH}-$ metre (Mettler Toledo) aracılığılla $\mathrm{pH}$ ölçümü yapılmıștır. Hasatta domates meyvelerindeki L, a, b, C ve h değerleri bir kolorimetre (CR-10 Plus model, KONICA MINOLTA) ile ölçülmüștür. Domates meyvelerinin sertlik ölçümlerinde dijital bir penetrometre'den yararlanılmıștır.

Denemeler sonucunda elde edilen verim ve kalite özelliklerine ilișkin tüm veriler varyans analizine tabi tutulmuștur. İstatiksel olarak farklı grupların belirlenmesinde Duncan çoklu karșılaștırma testinden yararlanılmıștır. İstatiksel analizlerin yapılmasında bir istatistik programı olan IBM SPSS 23 (Statistics for Windows, Version 23, Copyright, 2016, IBM Corp., Armonk, NY) kullanılmıștır. 


\section{BULGULAR VE TARTIȘMA}

\section{Sulama Suyu Miktarı ve Bitki Su Tüketimi}

Salçalık domatesin sulamasına 03.05.2019 tarihinde bașlanmıștır. Ekimden hasada kadar yağıș miktarı 130 mm olarak ölçülmüștür. Araștırma süresi boyunca her deneme parseline deneme gereği son sulama suyu kesinti tarihine kadar eșit miktarda su verilmiștir. Bu uygulamalara bağlı olarak, toplam sulama suyu miktarı deneme konularına göre 317 - 377 mm arasında değișmiștir. (Çizelge 2). Uygulanan sulama suyu, son sulama suyunun daha erken kesildiği tarihte daha az, hasat tarihine daha yakın zamanda kesilen uygulamada ise daha fazla olmuștur. Mevsimlik bitki su tüketimi, araștırılan deneme konularına göre farklıık göstermiștir. Hasattan 4 gün önce suyun kesildiği S1 konusunda domatesin mevsimlik su tüketimi 512 mm, 8 gün önce suyun kesildiği S2 konusunda 494 mm, 12 gün önce suyun kesildiği S3'te 486 mm ve 16 gün önce suyun kesildiği S4'te ise 475 mm olarak hesaplanmıștır. Mevsimlik uygulanan toplam sulama suyu miktarlarına bağlı olarak bitki su tüketim değerleri de farklılık göstermiș ve genelde sulama miktarındaki artıșla bitki su tüketimi de artmıștır (Çizelge 2). Araștırmanın yapıılığı bölgede (Bursa) yapılan bașka bir araștırmada Yazgan ve Demirtaș (2000), sırık domateste mevsimlik sulama suyu gereksiniminin 289.3436.9 mm arasında değiștiğini belirlemișlerdir. Kuscu vd. (2014b) salçalık domates için sulama suyu miktarının 2010 yılında 248 ile 455 mm ve 2011 yilında $321 \mathrm{~mm}$ ile $512 \mathrm{~mm}$ arasında değiștiğini bildirmiștir. Bu çalıșmadaki sonuçlara benzer olarak, uygulanan sulama suyu miktarının araștırmanın yapıldığı dönem içerisinde meydana gelen yağıșlardan etkilendiğini belirtmișlerdir. Özbahçe ve Tari (2010), sulama suyu miktarı ve mevsimlik bitki su tüketiminin sırasıyla 426-587 mm ve 525 ve $619 \mathrm{~mm}$ olarak belirlemiștir. Semiz ve Yurtseven (2010), damla sulama ve karık sulama için sulama suyu intiyacı ve mevsimlik bitki su tüketimini sırasıyla $722-876 \mathrm{~mm}$ ve $790-942 \mathrm{~mm}$ olarak raporlamıșlardır. Bitki su tüketimindeki farklılıların yetiștiricilik yapılan yerin iklim koșulları, toprak özellikleri ve çeșidin genetik özelliklerindeki farklılıklarından kaynaklandığı söylenebilir.

\section{Su Üretkenliği ve Sulama Suyu Üretkenliği}

Domatesin WP değerleri $13.1-21.6 \mathrm{~kg} \mathrm{~m}^{-3}$ arasında değișmiștir (Șekil 1). En yüksek WP değeri S2 deneme konusunda görülmüșken, en düșük WP değeri ise sulama suyunun hasattan 16 gün önce kesildiği S4 deneme konusunda tespit edilmiștir. S1 ve S2 deneme konularında WP değerleri arasında fazla fark söz konusu değil iken, sulamanın hasattan önce kesildiği zaman aralığı arttığı koșullarda (S3 ve S4) önemli derecede bir azalma meydana gelmiștir. Diğer taraftan, IWP değerleri ise 19.6-30.3 kg m-3 arasında değișmiștir. En yüksek IWP değeri S2 deneme konusunda görülmüșken, en düșük IWP değeri ise $\$ 4$ deneme konusunda görülmüștür.

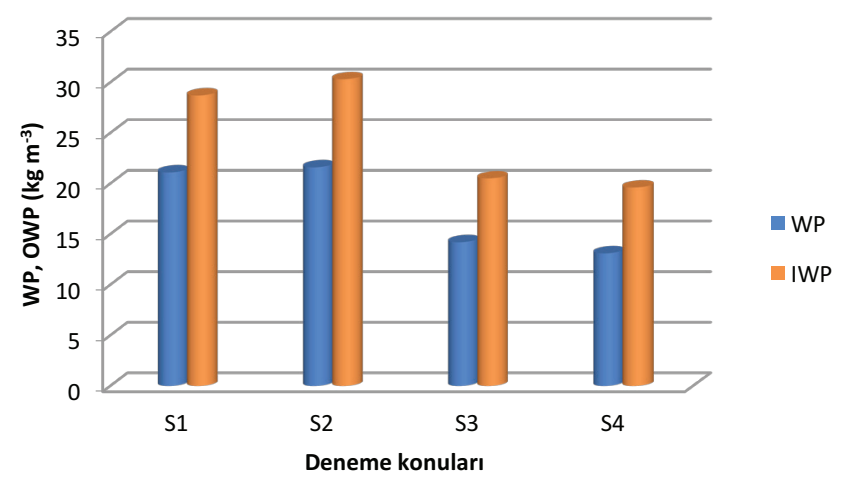

Șekil 1. Su üretkenliği (WP) ve sulama suyu üretkenliği (IWP) sonuçları

Figure 1. Results of water productivity and irrigation water productivity

Çanakkale ilinde yapılan bașka bir çalıșmada Yıldırım ve Bahar (2017), WP değerlerinin 7.31$8.65 \mathrm{~kg} \mathrm{~m}^{-3}$ arasında değiștiğini bildirmișlerdir. Kuscu vd. (2014a), Bursa ilinde domateste yaptıkları çalıșmada, WP ve IWP değerlerinin sırasıyla, 7.2$18.3 \mathrm{~kg} \mathrm{~m}^{-3}$ ile $8.2-27.5 \mathrm{~kg} \mathrm{~m}^{-3}$ arasında değiștiğini bildirmișlerdir. Çalıșmalar arasındaki söz konusu

Çizelge 2. Uygulanan sulama suyu miktarı, yağıș, toprak nem değișimi ve mevsimlik bitki su tüketimi değerleri Table 2. Amount of irrigation water applied, rainfall, soil moisture change values

\begin{tabular}{ccccc}
\hline Deneme konuları & $\begin{array}{c}\text { Uygulanan sulama suyu } \\
(\mathrm{mm})\end{array}$ & $\begin{array}{c}\text { Yağıș } \\
(\mathrm{mm})\end{array}$ & $\begin{array}{c}\text { Toprak nem değișimi } \\
(\mathrm{mm})\end{array}$ & $\begin{array}{c}\text { Mevsimlik bitki su tüketimi } \\
(\mathrm{mm})\end{array}$ \\
\hline S1 & 377 & 130 & +5 & 512 \\
S2 & 352 & 130 & +12 & 494 \\
S3 & 337 & 130 & +19 & 486 \\
S4 & 318 & 130 & +27 & 475 \\
\hline
\end{tabular}


farklılıkların nedenleri, çeșidin erkenci veya geççi olmasına bağı olarak üretim mevsimi boyunca uygulanan sulama suyu miktarı, yağıș miktarı, bitki su tüketimi, verim ve deneme konularındaki farklııklardan ileri geldiğini söylemek olasıdır.

\section{Domates Meyve Verimi}

Denemelerden elde edilen pazarlanabilir meyve verimi değerleri ve uygulamalara göre olușan Duncan gruplandırmaları șekil 2'de verilmiștir. Domatesin verim değerleri 108.2 ton ha-1 ile 62.4 ton ha-1 arasında değișmiștir. En yüksek verim değerleri S1 ve S2 konusundan elde edilirken istatistiksel olarak farklı bir grup olușturan S3 ve S4 konularında ise daha düșük verim değerleri saptanmıștır. Bu nedenle, önemli verim kayıpları yașamamak için sulamaların 12 veya 16 gün önce kesilmesi önerilmemektedir. Nas ve ark. (2017), İzmir-Torbalı bölgesinde tarla koșullarında hibrit CXD-263 sanayi domatesi çeșidi kullanarak yaptıkları çalıșma sonucunda en yüksek verimi 150.7 ton ha-1 ile siltli-tın bünyeli toprakta ve hasattan 10 gün önce son sulama uygulamasından elde etmișlerdir. López ve ark. (2001), İspanya'nın Extremadura bölgesinde hasattan en fazla 15 gün önce sulamanın kesilmesi halinde kabul edilebilir düzeyde verim elde edilebileceğini belirtmișlerdir. Bursa koșullarında daha önce gerçekleștirilen çalıșmada, Kușçu ve ark. (2014b) en yüksek salçalık domates verimini, tam sulama yapılan deneme konusundan 2010 yılı için 100.4 ton ha-1 ve 2011 yllı için ise 110.7 ton ha-1 olarak tespit etmișlerdir. Baydar ve Ünlü (2020), MersinTarsus ekolojik koșullarında Marmara F1 domates çeșidinde yürüttükleri çalıșmada enjeksiyon pompası ile yapılan fertigasyon yöntemiyle damla sulama koșulları altında en yüksek verimi 48.8 ton ha ${ }^{-1}$ olarak tam sulama konusundan elde ettiklerini bildirmișlerdir. Mersin koșullarında elde edilen verimler, bu çalıșmadan elde edilen verim

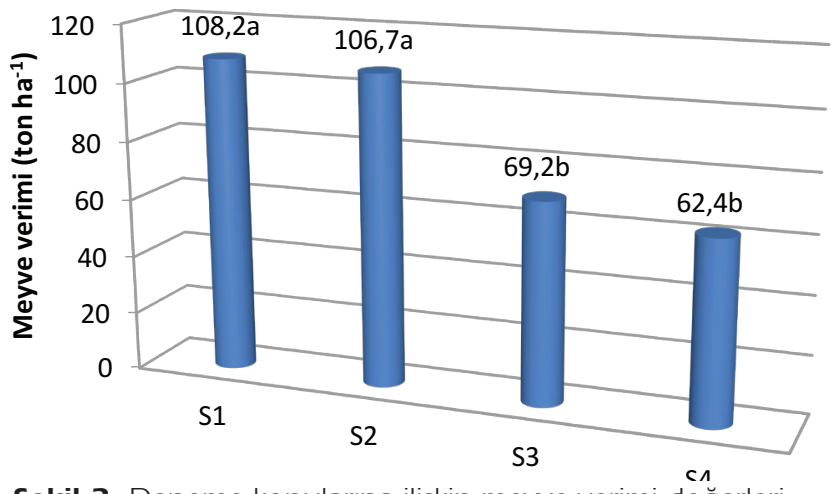

Șekil 2. Deneme konularına ilișkin meyve verimi değerleri Figure 2. Fruit yields values of experimental treatments

Not: F testine göre verim değerleri arasındaki farklııı $P<0.01$ düzeyinde önemlidir. Șekilde aynı harfle gösterilen değerler arasında Duncan'a göre $\mathrm{P}<0.05$ olasıık düzeyinde önemli bir farklıık bulunmamaktadır.

değerlerinin çok altındadır. Verimde meydana gelen farklılıklara toprak özellikleri, iklimsel faktörler, bitki çeșidi, sulama yönetimi ve programındaki farklılıkların neden olduğu söylenilebilir.

\section{Domates Meyvelerinin Kalite Özellikleri}

Hasatta domates meyveleri üzerinde yapılan bazı kalite ölçümlerine ilișkin sonuçlar Çizelge 3'te verilmiștir. En yüksek tek meyve ağırlığı değerleri sırası ile $71.7 \mathrm{~g}$ ve $70.3 \mathrm{~g}$ ile sırasıyla S1 ve S2 konularından elde edilmiștir. Sulamanın hasattan 4 ve 8 gün önce kesilmesi arasında çok fark bulunmamasına rağmen, diğer deneme konuları ile aralarında önemli bir düșüșün olduğu görülmüștür. Bunun nedeninin, uygulanan sulama suyu miktarındaki azalmaya bağı olarak meyvenin yeterli iriliğe ulașamadığı ve bu yüzden birim meyve ağırlığında da azalıș olduğu söylenebilir Nas vd. (2017), son su uygulamasının hasat tarihinden 5 gün önce yapıldığı uygulamada, ortalama meyve ağırlığını 67.5 g, 10 gün önce yapıldığında $68.2 \mathrm{~g}$ ve 15 gün önce yapıldığında ise $64.8 \mathrm{~g}$ olarak tespit etmișlerdir. Bu çalıșmada, sulamanın hasattan 4 ve 8 gün önce kesildiği durumlarda elde edilen birim meyve ağırlığı değerleri belirtilen araștırmacıların

Çizelge 3. Domates meyvelerinin tek meyve ağılığı, briks, $\mathrm{pH}$, sertlik ve renk parametreleri $(\mathrm{L}, \mathrm{a}, \mathrm{b}, \mathrm{C}$ ve h) Table 3. Single fruit weight, brix, $\mathrm{pH}$, hardness and color parameters of tomato fruits $(L, a, b, C$ and $h)$

\begin{tabular}{|c|c|c|c|c|c|c|c|c|c|}
\hline \multirow{2}{*}{ Deneme konusu } & \multirow{2}{*}{$\begin{array}{l}\text { Tek Meyve Ağırlığı } \\
\text { (g) }\end{array}$} & \multirow{2}{*}{ Briks } & \multirow{2}{*}{$\mathrm{pH}$} & \multirow{2}{*}{$\begin{array}{c}\text { Sertlik } \\
\text { (kg) }\end{array}$} & \multicolumn{5}{|c|}{ Renk Parametreleri } \\
\hline & & & & & $\mathrm{L}$ & a & b & C & $\mathrm{h}$ \\
\hline S1 & 71,71 а & $5,70 \mathrm{~b}$ & 4,64 & $0,86 \mathrm{~b}$ & 37,6 & 37,77 & 26,33 & 46,03 & 34,83 \\
\hline$S 2$ & $70,32 \mathrm{ab}$ & $5,76 \mathrm{~b}$ & 4,72 & $0,87 \mathrm{~b}$ & 37,03 & 36,93 & 26,9 & 45,7 & 36 \\
\hline S3 & $58,97 \mathrm{bc}$ & 6,13 ab & 4,68 & 0,99 ab & 36,93 & 36,37 & 25,73 & 44,33 & 35,2 \\
\hline S4 & $56,62 c$ & 6,53 a & 4,82 & 1,13 a & 37,17 & 38,4 & 25,83 & 46,3 & 33,93 \\
\hline Önem & * & * & öd & * & öd & öd & öd & öd & öd \\
\hline
\end{tabular}

*P<0.05 düzeyinde önemli. öd: önemli değil. Aynı sütunda aynı harfle gösterilen değerler arasında Duncan’a göre P<0.05 olasılık düzeyinde önemli bir farklıık bulunmamaktadır. 
sonuçları ile benzerlik göstermektedir. Bursa koșullarında gerçekleștirilen çalıșmada, Kuscu ve ark. (2014b) en yüksek birim meyve ağırlığını ortalama 66.1 g olarak bitki büyüme mevsimi boyunca tam sulamanın yapıldığı koșullarda elde etmișlerdir. Mahadeen vd. (2011) yaptıkları çalıșmada en yüksek birim meyve ağırlığını tam sulamanın yapıldığı koșullarda elde etmișlerdir. Birim meyve ağırlığında meydana gelen farklılıkların nedeni olarak toprak özellikleri, iklimsel faktörler, bitki çeșidi, yetiștirme koșulları, sulama yöntemi ve programındaki farklılıklar gösterilebilir.

Salçalık domates meyvelerindeki en önemli kalite parametrelerinden biri de suda çözünür kuru madde veya yaygın olarak kullanılan adıyla brikstir. Genellikle fabrikalarda ișlenen domates salçasının 28-30 brikste olması istenir. Bu nedenle çok büyük miktarlarda domatesin ișlendiği bir fabrikaya gelen hammaddenin briksinin yüksek olması arzu edilir. Böylece hammaddenin salçaya ișlenmesi için gerekli olan enerji maliyetlerinde briks değerinin artıșı ile bir azalma olacaktır. Bu çalıșmada, en yüksek briks değerleri S4 ve \$3 konularından elde edilmiș, istatistiksel olarak farklı bir grup olușturan S1 ve S2 konularında ise daha düșük briks değerleri saptanmıștır (Çizelge 3). Elde edilen sonuçlara göre, hasattan önce sulama zamanının kesilme süresi arttıkça briks değerleri de artmıștır. Uygulanan sulama suyu azaldıkça veya sulamanın hasattan önce kesilme süresi arttıkça briks değerlerinde de artıș olduğu önceki çalıșmalarda da bildirilmiștir (Lopez vd., 2001 ; Nas vd., 2017).

Yapılan istatistiksel analiz sonuçlarına göre, deneme konularının $\mathrm{pH}$ değerlerini önemli düzeyde etkilemediği tespit edilmiștir (Çizelge 3). İstatistiksel olarak önemsiz olmakla birlikte en düșük pH değeri (4.64) S1 konusunda ölçülürken en yüksek pH değeri (4.82) ise S4 konusunda Ölçülmüștür. Kuzucu vd. (2004), Koral, Mobil ve H-2274 domates çeșitlerinin sırasıyla 4.31, 4.33 ve $4.33 \mathrm{pH}$ değerine sahip olduğunu raporlamıșlardır. Nas vd. (2017) tarafından yapılan çalıșmada, pH değerleri 4.91-4.98 arasında belirlenmiștir. Elde edilen sonuçlar daha önce raporlanan sonuçlarla paralellik göstermektedir.

Sertlik, gerek sofralık gerekse salçalık domates meyve kalitesinin saptanmasındaki en önemli parametrelerden biridir (Batu, 1998; Yaylalı ve Çiftçi, 2008). Deneme konularının meyve eti sertliği üzerine etkisi $P<0.05$ önem düzeyinde istatistiksel olarak önemli bulunmustur. Sulamanın hasattan önce kesilme zamanı uzadıkça göreceli olarak meyve eti sertliği de artmıș ve en büyük meyve sertliği değerleri 1.13 kg ve $0.99 \mathrm{~kg}$ olarak sırasıyla S4 ve S3 konularından elde edilmiștir. Diğer taraftan S1 ve S2 konularının meyve eti sertliği değerleri arasında anlamlı bir farklılık gözlenmemiș ve daha düșük sertlik olușmuștur (Çizelge 3). Nas vd. (2017), hasat tarihinden 5 gün önce son sulama uygulamasında meyve sertliği değeri 34.92 N (3.56 kg), 10 gün önce son sulama uygulamasında $34.04 \mathrm{~N}$ (3.47 kg), 15 gün önce son sulama uygulamasında ise 37.93 N $(3.86 \mathrm{~kg})$ olarak belirlemișlerdir. Özbahçe ve Padem (2007), en yüksek meyve sertlik değerine Keban F1 (1.826 kg/ $\left.\mathrm{cm}^{2}\right)$ en düșük meyve sertlik değerine ise Peto $86\left(0.983 \mathrm{~kg} / \mathrm{cm}^{2}\right)$ çeșidinin sahip olduğunu raporlamıșlardır. Kuzucu vd. (2004), bu değerleri 1.06-1.60kg/ $\mathrm{cm}^{2}$ arasında bulmușlardır. Bu çalıșmadan elde edilen meyve sertliği değerleri, daha önce yürütülen benzer çalıșmalardan elde edilen değerlerden farklılıklar göstermektedir. Bunun sebebinin denemede kullanılan çeșitlerin farklı olmasının yanı sıra iklimsel özellikler ve hasat olgunluğu dönemi farklılığından da kaynaklanmıș olabileceği düșünülmektedir.

Salçalık domateste aranan diğer önemli bir kalite parametresi de renktir. Renk parametrelerine ilișkin sonuçlar Çizelge 3'te verilmiștir. Buna göre, L (parlaklık) değerlerinin 36.93-37.60, a (kırmızılık) değerlerinin 36.37-38.40, b (sarılık) değerlerinin 25.73-26.90 aralığında değiștiği belirlenmiș ancak sulamanın hasattan önce kesilme zamanının bu parametreler üzerinde istatistiksel olarak önemli bir etkisi olmadığı bulunmuștur. Renk berraklığı (C) ve ton açısı (h) değerlerinin değișimi ise sırasıyla 44.3346.30 ve 33.93-36.00 olarak elde edilmiștir. Elde edilen sonuçlar arasında istatistiksel olarak farklılık görülmemesi, sulamanın hasattan önce kesilme zamanının söz konusu renk parametreleri üzerinde etkisinin olmadığını göstermektedir. Yapılan diğer çalıșmalarda deneme konularına göre L, a, b değerlerinde önemli farklılıklar görülmemiștir (Ulukapı vd., 2009; Atikmen ve Kütük,2014).

\section{SONUC}

Bu çalıșmada son sulamanın kesilme zamanı meyve verimi, briks değeri, birim meyve ağırlığı ve meyve sertliği üzerindeki etkisi istatiksel olarak önemli $(P<0.05)$ bulunmuștur. Buna göre, en yüksek verim ve birim meyve ağırlığı değerleri en 
fazla sulama suyunun uygulandığı hasattan 4 gün önce sulamanın kesildiği deneme konusundan elde edilmiștir. Hasattan önce sulamanın kesildiği gün sayısına bağlı olarak uygulanan sulama suyu miktarı azaldıkça diğer bir ifadeyle hasattan önce sulamanın kesildiği gün sayısı arttıkça briks değerinde bir artıș gerçekleșmiș ve en yüksek briks değeri 6.53 ile hasattan 16 gün önce sulamanın kesildiği deneme konusunda saptanmıștır. Sulamanın hasattan önce kesilme zamanı uzadıkça göreceli olarak meyve eti sertliği de artmıș ve en büyük meyve sertliği değerleri son sulamanın hasattan 16 gün ve 12 gün önce yapıldığı deneme konularından elde edilmiștir. Diğer taraftan son sulamanın hasattan 4 gün ve 8 gün önce yapıldığı deneme konularında meyve eti sertliği değerleri arasında anlamlı bir farklıık gözlenmemiș ve daha düșük sertlik olușmuștur. Meyve $\mathrm{pH}$ değerleri ile renk parametreleri üzerine sulama konularının etkisi önemsiz bulunmuștur.

Elde edilen sonuçlar, damla sulama koșulları altında uygun bir verim ve kalite dengesinin sağlanması için hasattan 8 gün önce sulamalara son verilmesinin yararlı olacağını göstermektedir. Son sulamanın hasattan 8 gün önce yapıldığı deneme konusunda uygulanan sulama suyu miktarı 352 mm ve mevsimlik bitki su tüketimi 494 mm olarak belirlenmiștir. Bu deneme konusunda

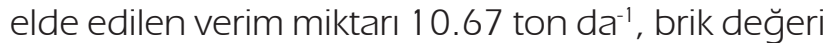
5.76, pH değeri 4.72, tek meyve ağırlığı $70.32 \mathrm{~g}$ ve meyve sertliği 0.87 kg olarak hesaplanmıștır.

\section{KAYNAKLAR}

Aguayo IA, Fortuny RS, Belloso OM (2009). Volatile compounds and changes in flavour-related enzymes during cold storage of high intensity pulsed electric field and heatprocessed tomato juice. Journal of the Science of Food and Agriculture, 90:1597-1604.

Atikmen NC, Kütük C (2014). Sakarya Akgöl organik toprağının domates bitkisinin kalite parametreleri üzerine etkisi. Trakya University Journal of Natural Sciences, 15(2): 89-94.

Batu A (1998). Some factors affecting on determination and measurement of tomato

firmness. Turkish Journal of Agriculture and Forestry, 22 $411-418$

Baydar A, Ünlü M (2020). Farklı fertigasyon teknikleri ve su kısıntısı koșullarında domates bitkisinin su verim ilișkilerinin belirlenmesi. Toprak Su Dergisi, 9(2): 116-121.

Bos MG (1980). Irrigation efficiencies at crop production level. ICID Bull. 29: 18-25.

Çetin Ö, Uygan D (2008). The effect of drip line spacing, irrigation regimes and planting geometries of tomato on yield, irrigation water use efficiency and net return. Agricultural Water Management, 95: 949-958.
Cetin Ö, Uygan D, Boyaci H (2008). Tomato irrigation scheduling improved by using percent canopy cover and crop developmental stage. Australian Journal of Agricultural Research, 59(12): 1113-1120.

Garrity PD, Watts DG, Sullivan CY, Gilley JR (1982). Moisture deficits and grain sorghum performance: evapotranspiration-yield relationships, Agronomy Journal, 74: 815-820.

Güvenç I (2019). Türkiye'de domates üretimi, dıș ticareti ve rekabet gücü. Kahramanmaraș Sütçü İmam Üniversitesi Tarım ve Doğa Dergisi, 22(1): 57-61.

Helyes L, Lugasi A, Pék Z (2012). Effect of irrigation on processing tomato yield and antioxidant components. Turkish Journal of Agriculture and Forestry, 36: 702-709.

Johnstone PR, Hartz TK, LeStrange M, Nunez JJ, Miyao EM (2005). Managing fruit soluble solids with late-season deficit irrigation in drip-irrigated processing tomato production. HortScience, 40(6): 1857-1861.

Jumah R, Al-Asheh S, Banat F, Al-Zoubi K (2007). Influence of salt, starch and ph on the electroosmosis dewatering of tomato paste suspension. Journal of Food, Agriculture \& Environment 5(1): 34-38.

Kelebek H, Selli S, Kadiroglu P, Kola O, Kesen S, Uçar B, Cetiner B (2017). Bioactive compounds and antioxidant potential in tomato pastes as affected by hot and cold break process. Food Chemistry, 220: 31-41.

Kuscu H, Turhan A, Ozmen N, Aydinol P, Demir AO (2014a). Optimizing levels of water and nitrogen applied through drip irrigation for yield, quality, and water productivity of processing tomato (Lycopersicon esculentum Mill.) Horticulture Environment \& Biotechnology, 55(2): 103114.

Kuscu H, Turhan A, Demir AO (2014b). The response of processing tomato to deficit irrigation at various phenological stages in a sub-humid environment. Agricultural Water Management, 133: 92-103.

Kuzucu C, Kaynas K, Kuzucu FC, Erken NT, Kaya S, Daydır HU (2004). Bazı domates çeșitlerinin verim ve kalite özelliklerinin belirlenmesi. V. Sebze Tarımı Sempozyumu Bildiri Kitabı: 288-294. 21-24 Eylül, Çanakkale.

Lopez J, R Ballesteros, R Ruiz and A Ciruelos (2001). Influence on tomato yield and brix of an irrigation cut-off fifteen days before the predicted harvest date in southwestern Spain. Acta Horticulturae, 542: 117-125.

Mahadeen AY, Mohawesh OE, Al-Absi K, Al-Shareef W (2011). Effect of irrigation regimes on water use efficiency and tomato yield (Lycopersicon esculentum Mill.) grown in an arid environment. Archives of Agronomy and Soil Science, 57(1): 105-114

Marouelli WA, Silva W LC, Moretti CL (2004). Production, quality and water use efficiency of processing tomato as affected by the final irrigation timing. Horticultura Brasileira, 22(2): 226-231

Nas Y, Duman I, UI MA (2017). Farklı Toprak Tiplerinde Yetiștirilen Sanayi Domatesinde Son Sulama Uygulamalarının Verim ve Meyve Kalite Özelliklerine Etkisi. Ege Üniversitesi Ziraat Fakültesi Dergisi, 54 (2):223-230 
Özbahçe A, Padem H (2007). Üstün verim ve teknolojik özelliklere sahip bazı salçalık domates çeșitlerinin Isparta koșullarına uygunluğunun belirlenmesi. Süleyman Demirel Üniversitesi Fen Bilimleri Enstitüsü Dergisi, 11 (2):128-133.

Özbahce A, Tari AF (2010). Effects of different emitter space and water stress on yield and quality of processing tomato under semi-arid climate conditions. Agricultural Water Management, 97: 1405-1410.

Patanè C, Tringali S, Sortino O (2011). Effects of deficit irrigation on biomass, yield, water productivity and fruit quality of processing tomato under semi-arid mediterranean climate conditions. Scientia Horticulturae., 129(4): 590-596.

Semiz D, Yurtseven E (2010). Salinity distribution, water use efficiency and yield response of grafted and ungrafted tomato (Lycopersicon esculentum) under furrow and drip irrigation with moderately saline water in Central Anatolian Condition. Gaziosmanpașa Üniversitesi Ziraat Fakültesi Dergisi, 27(2): 101-111.

Tarı AF, Sapmaz M (2017). Farklı sulama düzeylerinin serada yetiștirilen domatesin verim ve kalitesine etkisi. Toprak Su Dergisi, 6(2): 11-17.

TÜiK (2018). Türkiye İstatistik Kurumu, www.tuik.gov.tr/ temel istatistikler (Erișim Tarihi: 21.09.2019).

Ulukapı K, Ercan N, Onus AN (2009). Farklı terbiye șekillerinin ve dikim mesafelerinin M19 salkım domates çeșidinde verim ve kalite üzerine etkileri. Akdeniz Üniversitesi Ziraat Fakültesi Dergisi, 22(2): 233-238.

Yaylalı IK, Çiftçi N (2008). Tuzlu sulama suyu uygulamalarının domates meyvesinde bazı kimyasal kalite unsurlarına etkisi. Selçuk Üniversitesi Ziraat Fakültesi Dergisi, 22 (45): 29-39.

Yazgan S, Demirtaș Ç (2000). Bursa-Iznik yöresinde sırık domates sulamasında damla sulama yönteminin kullanımı ve karșılașılan sorunlar. Uludağ Üniversitesi Ziraat Fakültesi Dergisi, 19(1): 91-100.

Yıldırım O (2008). Sulama Sistemlerinin Tasarımı. Ankara Üniversitesi Ziraat Fakültesi Ders Kitabı, Yayın No: 1565 , Ankara, $354 \mathrm{~s}$.

Yıldırım M, Bahar E (2017). Water and radiation useefficiencies of tomato (Lycopersicum esculentum L.) at three different planting densities in open field. Mediterranean Agricultural Sciences, 30(1): 39-45. 